\author{
UNIVERSIDADE DE SÃO PAULO \\ FACULDADE DE ODONTOLOGIA DE BAURU
}

CAMILA PERFEITO EVANGELISTA DA SILVA

\title{
Effect of CAD/CAM abutment height and cement type on the retention of zirconia crowns
}

Efeito da altura do pilar CAD / CAM e tipo de cimento na retenção de coroas de zircônia 

Effect of CAD/CAM abutment height and cement type on the retention of zirconia crowns

\section{Efeito da altura do pilar CAD / CAM e tipo de cimento na retenção de coroas de zircônia}

Dissertação constituída por artigo apresentada a Faculdade de Odontologia de Bauru da Universidade de São Paulo para obtenção do título de Mestre em Ciências no Programa de Ciências Odontológicas Aplicadas, na área de concentração Reabilitação Oral.

Orientadora: Profa. Dra. Simone Soares 


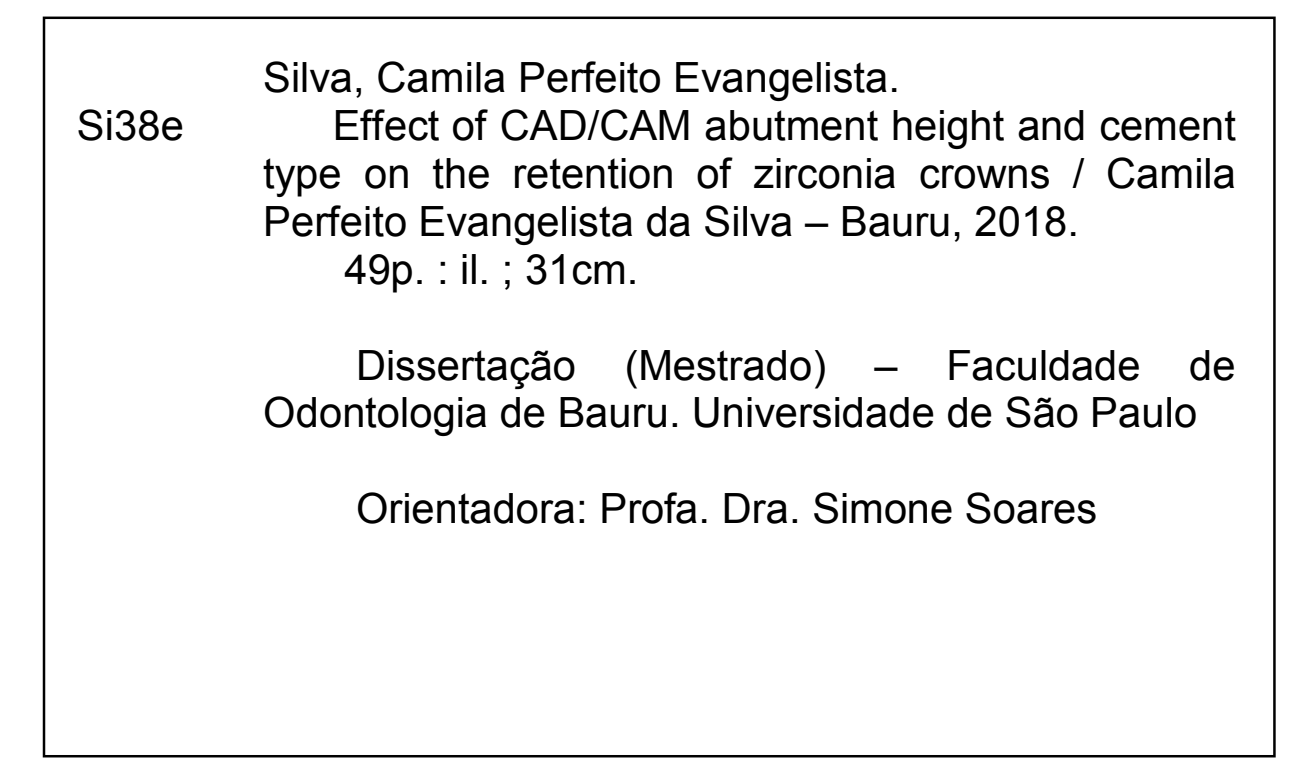

Autorizo, exclusivamente para fins acadêmicos e científicos, a reprodução total ou parcial desta dissertação/tese, por processos fotocopiadores e outros meios eletrônicos.

Assinatura:

Data: 
(Cole a cópia de sua folha de aprovação aqui) 



\section{DEDICATÓRIA}

À Deus, por me sustentar no caminho, me proteger e me fortalecer. Ele que me deu forças para que eu não desistisse e me guiou para completar minha caminhada e realizar este sonho. Obrigada Deus, minha fé é muito grande e sem isso eu nada seria.

À minha mãe, Adriana Froio Perfeito e à minha avó, Adalgiza Froio Perfeito, pessoas mais importantes na minha vida, meu porto-seguro, minha base, aquelas que sempre fizeram de tudo por mim, dedico minha vida à vocês. Tudo o que sou e o que faço é pensando em vocês (por vocês). Amo vocês!

Aos meus queridos professores, Simone Soares e Estevam Augusto Bonfante, vocês são os responsáveis por esse trabalho e pela realização desse sonho, desde o principio me apoiaram e acreditaram muito em mim, serei eternamente grata!

Muito obrigada! 



\section{AGRADECIMENTOS}

Em especial, a minha orientadora, Profa. Dra. Simone Soares, desde a minha graduação podendo compartilhar dessa sua alegria e simplicidade. Acho que nunca falei, mas minha admiração pela sua pessoa vai muito além do profissional, é pela mulher forte e guerreira que és! Obrigada por me amparar, por não desistir de mim e principalmente por todas as palavras de apoio. É uma honra ser sua orientada!

Ao Prof. Dr. Estevam Augusto Bonfante, que me "adotou" e sem nem titubear me acolheu em sua "família científica". Obrigada por compartilhar comigo sua sabedoria da forma mais brilhante e com tanto amor. Esse trabalho é fruto da sua generosidade e do grande amor que o senhor tem em ensinar. Espero ter a oportunidade de passar para frente um pouco do que o senhor fez por mim, muito obrigada!

À Faculdade de Odontologia de Bauru, Universidade de São Paulo, na pessoa de sua Diretora, Profa Dra Maria Aparecida de Andrade Moreira Machado, minha segunda casa desde a graduação. Tenho o maior orgulho de ser filha dessa escola tão admirada, desde a graduação.

Ao Departamento de Prótese da FOB-USP, representado pelo Prof. Dr. José Henrique Rubo, fazendo-se membro junto aos professores doutores: Paulo César Rodrigues Conti, Ana Lúcia Pompeia Fraga de Almeida, Carlos dos Reis Pereira de Araújo, Gerson Bonfante, Karin Hermana Neppelenbroek, Lucimar Falavinha, Pedro César Garcia de Oliveira, Renato de Freitas, Vinicius Carvalho Porto e Wellington Cardoso Bonachela. A admiração e inspiração que tenho por todos são imensuráveis. Agradeço por compartilharem seus conhecimentos durante toda minha formação. 

Ao Prof. Dr. Luis Fernando Pegoraro, grande nome da odontologia, e ao mesmo tempo um ser humano extremamente simples e próximo. Obrigada por me ensinar tudo o que sei de Reabilitação Oral e por me inspirar sempre. Exemplo de educador e de ser humano, foi uma honra poder compartilhar horas de convívio!

Ao meu querido Prof. Dr. Accácio Lins Valle, me acolheu tão bem nas clínicas de reabilitação e tornou tudo mais prazeroso e divertido. Obrigada por cuidar de mim e me ensinar tantas coisas.

À secretária do Departamento de Prótese Déborah Andrea Riêra Blasca, por toda paciência e comprometimento. Aos funcionários: Cleide Vital Martins, Marcelo Henrique G. de Souza, Valquíria F. Nogueira e Ziley Mara Clepso de Castro, pela atenção e solicitude. Em especial ao técnico de prótese Reivanildo F. Viana por toda a ajuda no meu trabalho, sempre com disposição e boas ideias.

À equipe de pós-graduaçao da FOB-USP, Cleusa Gonsalves Leite e Hebe Joselina de Freitas Pereira, pessoas tão queridas que sempre nos ajudaram em tudo na clinica de pós-graduação com muito carinho e alegria. Ás secretárias Ana Letícia Polombo Momesso, Fátima Cassador Carvalho e Leila Regina da Silva Yerga Sanchez.

Aos meus colegas de pós graduação: Ilana Ramalho, Andrea Falcão, Thereza Pacheco, Verena Cunha, Patrick Alves, Oscar Marcillo, Vinicius Rizzo, Guilherme Moreira, Fernanda Furtado Piras, Fernanda Ferruzi, Leonardo Marques, Denise Gusmão, Vinicius Fardin, Henrique Quevedo, Janaina Maciel, Ana Paula Chappuis, Leadiane Sandes, Jéssica Moreno, Cindy Ruiz Garcia, Dyna Mara, Cristiane Marques, Bárbara Margarido Brondino, Milena Steluti Marques, Letícia Fiedler, Laila Aguiar, Clara Fassoni Bonachela, Adolfo Coelho, Rodrigo Moreira, Nicole Freitas, Thais Fuzer, Luiza Guerrini por todo conhecimento compartilhado e pelo companheirismo de sempre. 

Á amiga Maira M. M. Falzoni, aquela "irmã" com quem pude compartilhar todos os momentos felizes e tristes na minha vida. Tenho profunda admiração por você; sua força, determinação e generosidade são qualidades exemplos para qualquer pessoa. É uma das minhas maiores incentivadoras, só tenho a agradecer pela amizade sincera, pelas horas de conversa e concelhos e por todo amor de irmã que construímos. Você é um presente para mim! Estendo esse agradecimento, para sua família, que sempre me acolheu com maior alegria lá em Avencas, lugar de paz e tranquilidade. Te amo, amiga!

Á amiga Camila Machado, por quem tenho profundo carinho e admiração. Você é uma pessoa incrível, foi essencial na minha vida em um momento tão delicado, me ajudou, esteve do meu lado e sempre me incentivou á crescer. Amiga, devo muito desse trabalho á você! Estendo aqui, um agradecimento especial ao Ernesto Benalcázar, obrigada amigo, por todo apoio, sou sua fã! Parabéns ao Prof. Dr. Estevam Augusto Bonfante, sua equipe de pesquisa é incrivel e obrigada mais uma vez por me incluir nela!

Ás amigas, Brunna Mota Ferrairo e Samira Sandy Ferreira Strelhow. Sem dúvidas minha caminhada na pós-graduação foi muito melhor por que tive vocês ao meu lado!

Aos pacientes que pude acompanhar durante esta trajetória, pela compreensão e colaboração durante o aprendizado.

Ao Conselho Nacional de Desenvolvimento Científico e Tecnológico (CNPq), pela bolsa de mestrado, auxílio indispensável para realização deste trabalho.

Aos professores integrantes da banca examinadora, pela disponibilidade em analisar, avaliar e contribuir para aprimorar o presente trabalho. 

Á minha mãe Adriana Froio Perfeito, minha melhor amiga, meu porto seguro, obrigada por me fazer ver o lado bom das coisas sempre. Á minha avó, Adalgiza Froio Perfeito, exemplo de garra e responsabilidade, obrigada por doar um pedaço de sua vida para cuidar de mim! Aos meus padrinhos Emerson Froio Perfeito, Danielle de Araujo Fioretti Perfeito e Dulcineia Froio, obrigada por me amarem e cuidarem de mim como filha. Aos meus tios Ricardo Froio Perfeito e Aline Perfeito, por toda a torcida e incentivo. Ao meu irmão Eduardo Perfeito, obrigada por me amar e se preocupar comigo. Sem o apoio, dedicação e torcida de vocês seria muito mais difícil. Amo vocês!

Ao meu namorado e melhor amigo, André Rodrigues Alvarez. Entrou na minha vida para ser além de namorado, o meu maior incentivador. Obrigada por ser tão presente em minha vida, me apoiar sempre, me fazer sorrir não importando o momento e por acreditar em mim. Agradeço principalmente por somar a minha vida, compartilhar os sonhos e caminhar ao me lado me oferecendo todo amor e parceria. Eu amo você!

Aos meus amigos do coração, Thales Ricardo Lulo Galitesi e Járede César Martins, que mesmo longe sempre estiveram presente na minha vida, participando de todos os momentos e torcendo muito por mim. Que nossa amizade seja para sempre.

Aos meus amigos de longa data, Nathan Benetti, Lucas Pitta Alfeu Domingues, José Inácio Feijão, Rodrigo Cordeiro, Luan Oliveira e Fernanda Nascimento. Aos meus amigos da graduação Larissa Vasconscelos, Patrícia Kerges, Vinicius Pollo, Giovanni Liberatti, Melissa Nomyama e Isabela Brandt. $E$ às minhas amigas do dia-a-dia, Emilia Pelegrini, Fernanda Barros, Priscila Xavier, Dani Ceollin e Dayana Crespi. Obrigada por se fazerem sempre presentes de alguma forma, cada um de vocês tem um espaço especial no meu coração. Amo vocês!

A todos que sempre pensaram e torceram por mim, meu muito obrigada! 

"Aqueles que passam por nós, não vão sós, não nos deixam sós. Deixam um pouco de si, levam um pouco de nós." 

ABStRACt 



\section{ABSTRACT \\ Effect of CAD/CAM abutment height and cement type on the retention of zirconia crowns}

Aim: To evaluate the effect of different Ti-base abutment heights and cement type on the pullout retention of zirconia-based restorations.

Methods: Identical crowns were designed in a CAD software to fit two different Tibase abutment heights, as follows ( $n=10 /$ group): (i) 4-mm-height Ti-base abutment (Tall), and (ii) 2.5-mm-height Ti-base abutment (Short). Four cement types were selected: (i) Temporary cement (Provisional); (ii) Glass-ionomer cement (Meron); (iii) self-adhesive resin cement (U200), and (iv) conventional resin cement (Ultimate) with universal adhesive for treatment of titanium and zirconia substrates. Pull-out testing was performed in a universal testing machine. Data were statistically evaluated through two-way analysis of variance following post-hoc comparisons by Tukey test.

Results: Tall Ti-base abutments demonstrated similar retention to short abutments when data is collapsed over cement $(p>0.74)$. Data evaluation as a function of cement type demonstrated the superiority of resin-based cements relative to provisional and glass-ionomer groups $(p<0.01)$. Retentiveness data as a function of both factors demonstrated similar force to dislodgment between tall and short abutments for all within cement comparisons ( $p>0.42)$, except for U200 ( $p=0.032$ ). Also, tall abutments cemented with Ultimate evidenced higher pull out values than U200 ( $p=0.043)$, and both were significantly more retentive than tall provisional and meron $(p<0.001)$. No significant difference was observed between U200 and Ultimate cements for short abutments $(p=0.758)$, and both presented statistically higher pullout values than provisional and glass-ionomer $(p=0.001)$.

Conclusions: While Ti-base abutment height have not influenced zirconia superstructure retentiveness, resin-based cements significantly evidenced higher retention than glass ionomer and temporary cements.

Key-words: CAD/CAM, Dental Implants, Abutment Design, Dental Cements, Zirconia. 




\section{RESUMO}

\section{Efeito da altura do pilar CAD / CAM e tipo de cimento na retenção de coroas de zircônia}

Objetivo: Avaliar o efeito de diferentes alturas de interface de Titânio (Ti) e diferentes tipos de cimento na retenção de coroas de zircônia.

Métodos: Coroas idênticas foram projetadas em um software de CAD capaz de adaptar duas alturas diferentes do pilar de interface de Ti: cada grupo foi composto de 10 amostras conforme se segue: (i) interface de Ti de $4 \mathrm{~mm}$ de altura (alto) e (ii) interface de 2,5 mm de altura (curto). Foram selecionados quatro tipos de cimento: (i) cimento temporário (Provisional); (ii) Cimento de ionômero de vidro (Meron); (iii) cimento resinoso auto-adesivo (U200) e (iv) cimento resinoso convencional (Ultimate) com adesivo universal para tratamento de substratos de titânio e zircônia. O teste de tração foi realizado em uma máquina de ensaio universal. Os dados foram avaliados estatisticamente através de análise de variância a dois critérios, após comparações pós-hoc pelo teste de Tukey.

Resultados: As interfaces de Ti demonstraram retenção semelhante aos pilares curtos quando os dados foram colapsados sobre o cimento ( $p>0,74)$. A avaliação dos dados em função do tipo de cimento demonstrou a superioridade dos cimentos à base de resina em relação aos grupos de cimentos temporário e de ionômero de vidro ( $p<0,01$ ). Os dados de retenção em função de ambos os fatores demonstraram força semelhante ao deslocamento, entre pilares altos e curtos, para todos dentro das comparações de cimento $(p>0,42)$, exceto para U200 $(p=0,032)$. Além disso, os pilares altos cimentados com Ultimate evidenciaram maiores valores de tração do que os cimentados com U200 ( $p=0,043$ ), e ambos foram significativamente mais retentivos do que o pilar alto cimentado com cimento Provisional e o Meron $(p<0,001)$. Não foi observada diferença significativa entre os cimentos U200 e Ultimate para pilares curtos $(p=0,758)$ e ambos apresentaram valores de tração estatisticamente mais elevados que os cimentos de ionômero de vidro e cimento temporário $(p=0,001)$.

Conclusões: Embora a altura da interface de Ti não tenha influenciado a retenção das coroas de zircônia, os cimentos resinosos resultaram em maior retenção do que o ionômero de vidro e cimentos temporários.

Palavras-chave: CAD, Implantes dentários, Cimentos dentários. 



\section{LIST OF ILLUSTRATIONS}

Figure 1 - Schematic with dimensions for the Ti-base abutments and crown ....29

Figure 2 - Pull Out retention values as a function of mean and $95 \%$ confidence

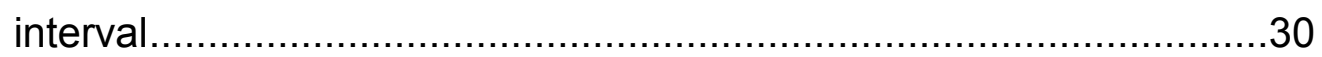





\section{TABLE OF CONTENTS}

1 INTRODUCTION

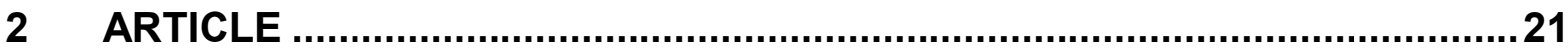

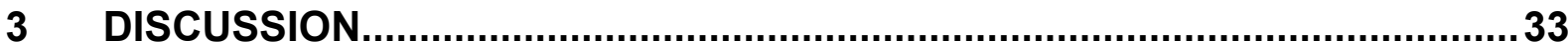

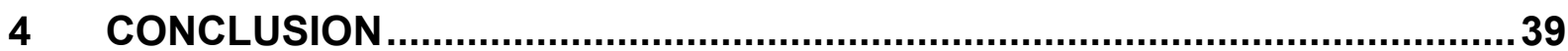

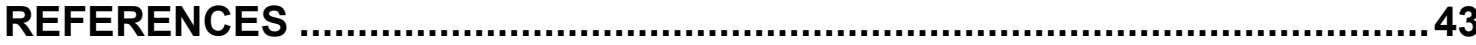

ANNEX 

1 INTRODUCTION 



\section{INTRODUCTION}

Implant dentistry is a well-established treatment option that has been demonstrating high success rates in long-term follow-up studies (KAROUSSIS et al., 2004; HJALMARSSON; GHEISARIFAR; JEMT, 2016). When implant surgical protocols are strictly followed, metallic device osseointegration is expected to be uneventful. Despite the high success rates, biological and technical complications are frequently described for implant-supported reconstructions (PJETURSSON, et al., 2004; SCHWARZ, et al., 2012). Although still debated, it seems that the rate of such complications in internally connected implants are lower compared to external connections (GRACIS, et al., 2012). In a systematic review that analyzed more than 1,000 patients, only $61.3 \%$ of them were free of any complication after 5 years in function (PJETURSSON, et al., 2004). Abutment or occlusal screw loosening was the most common technical complication (12.7\%), followed by crown loss of retention $(5.5 \%)$, veneer fracture $(4.5 \%)$, and screw and abutment fracture $(0.35 \%)$. Consequently, current research in implantology have been focused on the improvement of prostheses longevity and retrievability (PAPASPYRIDAKOS, 2012).

Most implant rehabilitations comprise one or two-piece restorations where a crown can be cemented or screwed on the abutment (HEBEL; GAJJAR, 1997; LEE; OKAYASU; WANG, 2010). Substantial literature findings are categorical concerning to the advantages and disadvantages of both prosthesis retention systems (GOODACRE; KAN; RUNGCHARASSAENG, 1999; PJETURSSON, et al., 2004; WITTNEBEN, et al., 2017). While screw-retained restorations are known for their retrievability, cement-retained advantages include enhanced esthetic, easy handling, reduced laboratory technique sensitivity, ability to correct minor casting misfits between the superstructure and abutment, prevention of microorganism colonization of the inner part of the implant, and possibility of implant alignment correction. Nonetheless, loss of retention is the weakness of such system along with periodontal concerns relative to remnants of cement in the gingival sulcus (WITTNEBEN, 2017).

Considering the increased use of the digital workflow in restorative dentistry, the use of abutments with geometry stored in CAD/CAM systems for rapid restoration 
fabrication, also known as Ti-Base abutments, has gained interest. The rationale behind its indication lies on the possibility of conventional or digital implant transfer for design of monolithic or bilayered restorations of any given material that will be cemented chairside and then screwed to the implant. Improved control of bonding procedures can be achieved specially during excess cement removal. This feature is advantageous since extraneous cement in the peri-implant tissue may lead to marginal bone loss. As a disadvantage, the screw access hole will still be visible which may impair excellent esthetic results (PAULETTO, LAHIFFE, WALTON, 1999; RODRIGUEZ, 2017).

Cementation protocols for Ti-base abutments have been scarcely explored (GEHRKE, 2014). There are several factors that may affect the final prostheses retention such as Ti-base height and texturization, cement type, superstructure fit, and surface treatment (KENT, KOKA, FROESCHLE, 1997; COVEY et al., 2000; SCHIESSL, 2013). When the prostheses material is zirconia, additional challenges are encountered for adequate bonding. Due to its high crystalline content and absence of a glass phase (GRACIS et al., 2015), zirconia demands different surface treatments, compared to other glass-matrix ceramics (INOKOSHI, et al., 2014), that should be carefully undertaken since loss of retention is an important issue affecting clinical success rates of zirconia prostheses (SAILER et al., 2016; PJETURSSON, et al., 2017). The use of temporary cements have been indicated as a safe alternative for implant-supported metalceramic crowns compared to conventional and resinbased cements (SCHWARZ et al., 2012). Also, the use of self-adhesive resin cements, indicated to bond all-ceramic crowns to titanium abutments, have been suggested as a straightforward alternative since the application of adhesive systems is not required. Self-adhesive cements comprise a single-step cement that contain a resin matrix packed with phosphoric groups that simultaneously react with the ceramic surfaces and have demonstrated satisfactory bond strength to zirconia (PASSOS, et al., 2010). However, the lack of an adhesive layer has been claimed to hamper bond strength (AB-GHANI, et al., 2015), suggesting that strategies, including the use of 10-methacryloyloxydecyl dihydrogenphosphate (MDP) based resin cements, may improve the bond between Ti-base abutments and zirconia crowns (PAPIA et al., 2014; OZCAN; BERNASCONI, 2011). 
The understanding of the relative retentiveness of Ti-base abutments to zirconia crowns using different cements should improve clinician's ability to choose a particular cementation protocol. Accordingly, this study sought to evaluate the effect of different Ti-base abutment heights and cement type on the pullout retention of zirconia-based restorations. The postulated null hypotheses were: (i) that Ti-base abutment height would not influence pullout retention values and (ii) cement type would not influence pullout retention values. 

2 ARTICLE 



\section{ARTICLE}

The article presented in this Dissertation was written according to International Journal of Prosthodontics instructions and guidelines for article submission (Annex) 


\section{EFFECT OF CAD/CAM ABUTMENT HEIGHT AND CEMENT TYPE ON THE RETENTION OF ZIRCONIA CROWNS}

\section{ABSTRACT}

Aim: To evaluate Ti-base abutment height and cement type on the retentiveness of zirconia-based restorations.

Methods: $4 \mathrm{~mm}$ - (Tall) and 2.5mm-height (Short) abutments along with temporary (Provisional), glass-ionomer (Meron), self-adhesive (U200) and conventional resin cement (Ultimate) were evaluated using pull-out testing ( $n=10$ crowns/group).

Results: Tall and short abutments demonstrated similar retention for all within cement comparisons, except U200 $(p=0.032)$. Resin cements exhibited superior retentiveness than others $(p<0.01)$. While no significant difference between resin cements for short abutments, Ultimate evidenced higher retention than U200 for tall abutments $(p=0.043)$.

Conclusions: Ti-base height has not influenced crown retentiveness; however, resin-based cements were significantly more retentive.

Key-words: CAD/CAM, Dental Implants, Abutment Design, Dental Cements, Zirconia. 


\section{INTRODUCTION}

Considering the increased use of the digital workflow in restorative dentistry, the indication of abutments with geometry stored in CAD/CAM systems for rapid restoration fabrication, known as Ti-Base abutments, has gained interest. Such abutments allow conventional or digital implant transfer for designing monolithic or bilayered restorations that will be cemented chairside and then screwed to the implant. Therefore, control of bonding procedures and retrievability comprise their main advantages.

Additionally, prostheses retention can be influenced by different parameters, such as abutment height and texturization, cement type, superstructure fit, and surface treatment, which have been scarcely explored for Ti-Base abutments. ${ }^{1,2}$ This study evaluated the effect of Ti-base abutment height and cement type on the pullout retention of zirconia-based restorations.

\section{MATERIALS AND METHODS}

Identical crowns were designed to fit two different Ti-base heights (Emfils, Itu, SP, Brazil), n=10/group: (i) $4 \mathrm{~mm}$ (Tall) and (ii) $2.5 \mathrm{~mm}$ height (Short) (Figure 1). Tibase abutments and their corresponding internal conical connection implants (Novo Colosso, Emfils, Itu, SP, Brazil) were embedded in acrylic resin (Jet, Clássico Artigos Odontológicos, São Paulo, SP, Brazil).

Four cement types were assessed: (i) Temporary (Provisional) (Temp-Bond, Kerr Orange, CA, EUA); (ii) Glass-ionomer (Meron) (Meron, Voco, Cuxhaven, Germany); (iii) self-adhesive resin cement (U200) (RelyX U200, 3M Oral Care, St. Paul, MN, USA), and (iv) conventional resin cement (Ultimate) (RelyX Ultimate, 3M) 
with universal adhesive (Scotchbond Universal, 3M). Abutments were torqued (32 N.cm) and cemented as per manufacturer's recommendations.

Pull-out testing was performed in a universal testing machine (Kratos, Sao Paulo, SP, Brazil) at a cross-head speed of $1 \mathrm{~mm} / \mathrm{min}$ until crown displacement and load drop. The force was recorded and statistically evaluated through two-way analysis of variance following post-hoc comparisons by Tukey test $(\alpha=.05)$.

\section{RESULTS}

Standard 4mm-height abutments (Tall) demonstrated similar retention to 2.5mm (Short) when data are collapsed over cement type ( $p>0.74)$ (Figure 2A). On the other hand, resin-based cements (U200 and Ultimate) presented significantly higher pullout values relative to provisional and glass-ionomer cements $(p<0.01)$, without significant difference between U200 and Ultimate and between provisional and glass-ionomer (data collapsed over Ti-Base height) ( $p>0.34)$ (Figure 2B).

Evaluation of pullout data as a function of both factors, Ti-Base height and cement, demonstrated similar force to dislodgment between tall and short abutments for all within cement comparisons $(p>0.42)$, except for U200 $(p=0.032)$ where short abutments were more retentive. While tall abutments cemented with Ultimate evidenced higher pullout values compared to U200 $(p=0.043)$, no significant difference was observed between U200 and Ultimate cements used in short abutments $(p=0.758)$. 


\section{DISCUSSION}

The current study evaluated the effect of different Ti-base abutment height and cement type on the pull-out retention of zirconia-based restorations. Overall, similar retentiveness between tall to short abutments was demonstrated, except for U200 when both factors were analyzed with short abutments outperforming tall. Such result is in contrast to previous literature findings which postulate that the higher the abutment's axial walls or the height to width ratio the better the effect on the uniaxial testing values due to higher contact area. ${ }^{3}$

Furthermore, resin-based cements presented significantly higher force to dislodgment relative to provisional and glass-ionomer groups, without significant difference between both resin cements and also between provisional and glassionomer cement (collapsed data). This rank order corroborates with previous studies that evaluated pullout retentiveness of metal abutments using different cements ${ }^{1,2}$. On one hand, the higher pull-out values of resin-based cements and absence of significant difference between them lies on their improved adhesion to zirconia due to phosphate groups content and similar composition (methyl methacrylate monomers $)^{4}$. On the other hand, the notably lower retention for glass-ionomer and provisional cements are based on the absence or weak bond to zirconia due to lack of any bonding agent ${ }^{5}$.

There is no determination based on what constitutes a minimum pullout value that provides long retentiveness to an implant supported rehabilitation so that the patient would not have to return for prostheses recementation at an unexpected time. Then, the current study provided a scenario of bonding behavior of various cements 
and abutment designs that may be used as a guide until clinical studies are conducted.

\section{CONCLUSION}

While Ti-base abutment height have not influenced zirconia superstructure retentiveness, resin-based cements significantly evidenced higher retention than glass ionomer and temporary cements.

Acknowledgements: To grant \# 2012/19078-7 São Paulo Research Foundation (FAPESP) - Young Investigators Awards, FAPESP EMU 2016/18818-8 and to Conselho Nacional de Desenvolvimento Científico e Tecnológico (CNPq), grant \# 309475/2014-7. 


\section{REFERENCES}

1. Garg P, Pujari ML, D RP, Khare S. Retentiveness of Various Luting Agents Used with Implant Supported-Prosthesis: An In vitro Study. J Oral Implantol 2014. Mar 3. [Epub ahead of print]

2. Schiessl C, Schaefer L, Winter C, Fuerst J, Rosentritt M, Zeman F, et al. Factors determining the retentiveness of luting agents used with metal- and ceramic-based implant components. Clin Oral Investig 2013;17:1179-1190.

3. Bernal G, Okamura M, Munoz CA. The effects of abutment taper, length and cement type on resistance to dislodgement of cement-retained, implantsupported restorations. J Prosthodont 2003;12:111-115.

4. Passos SP, May LG, Barca DC, Ozcan M, Bottino MA, Valandro LF. Adhesive quality of self-adhesive and conventional adhesive resin cement to Y-TZP ceramic before and after aging conditions. Oper Dent 2010;35:689-696.

5. Rohr N, Brunner S, Martin S, Fischer J. Influence of cement type and ceramic primer on retention of polymer-infiltrated ceramic crowns to a one-piece zirconia implant. J Prosthet Dent 2017. Apr 28. pii: S0022-3913(17)30134-8 doi: 10.1016/j.prosdent.2017.02.002. [Epub ahead of print] 


\section{LEGENDS FOR ILLUSTRATIONS}

Figure 1. Schematic with dimensions for the A) tall (4 mm height) and B) short (2.5 $\mathrm{mm}$ height) Ti-base abutments. C) Proximal view of the stl file with projections that were designed with a round perforation of $2 \mathrm{~mm}$ (depicted in figure $D$ ) to provide the attachment of stainless steel wires for pull-out testing. E) Occlusal view shows the projections located at the cusp regions to allow occlusal access for abutment screw torqueing after cementation.

Figure 2. Pull Out retention values as a function of mean and $95 \%$ confidence interval. A) Ti-base abutment height have not influenced pullout retention values. B) Resin-based cements evidenced significant higher retentiveness than provisional and meron. C) Tall and short abutments presented similar force to dislodgment for all within cement comparisons, except U200; and, resin-based tall and short abutments demonstrated higher retentiveness than their provisional and meron counterparts. Different symbols indicate significant difference between groups. 
A

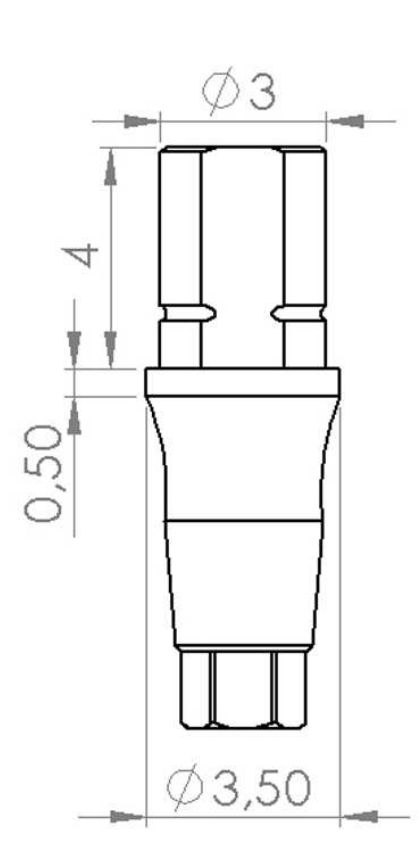

B
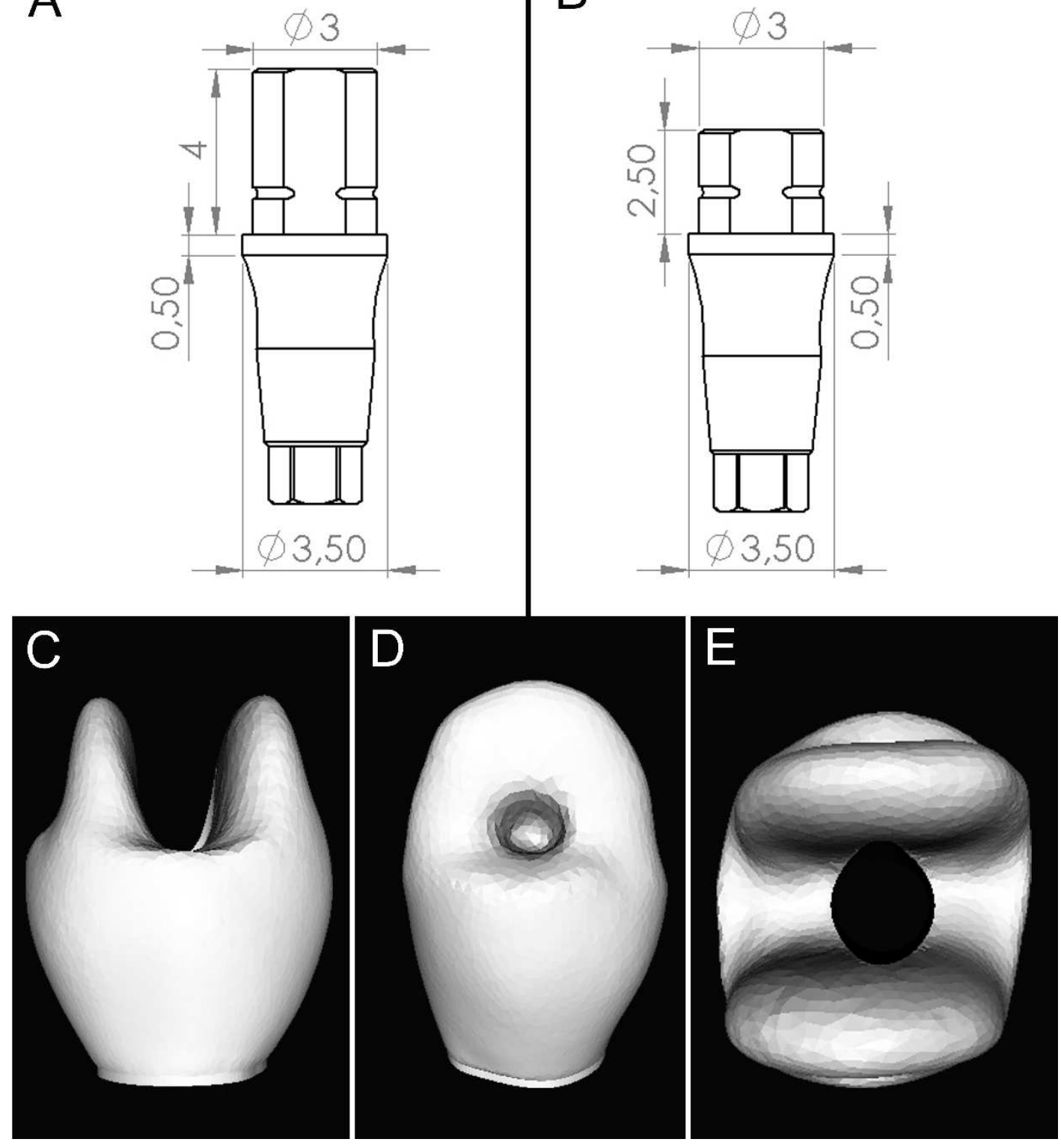

Fig 1 

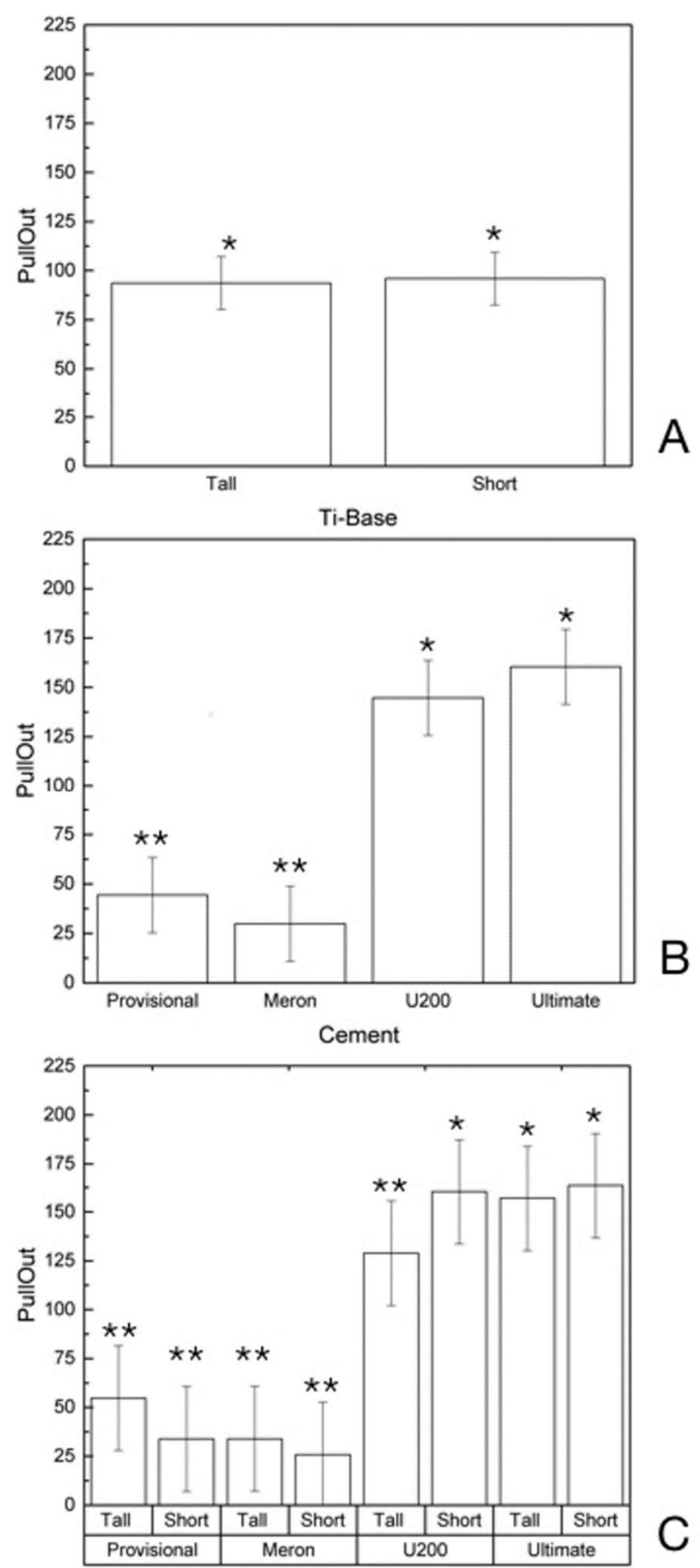

Fig 2 
3 DISCUSSION 



\section{DISCUSSION}

One of the critical factors for implant supported restorations success is the connection integrity between the prosthetic superstructure and implant (BREEDING, et al., 1992). Such integrity is provided as a function of implant-prostheses retention using screw and/or cement. The advantages and disadvantages of restoring dental implants with a screw- or cement-retained superstructure are well documented (GOODACRE; KAN; RUNGCHARASSAENG, 1999; PJETURSSON, et al., 2004; SCHIESSL, 2013), but less frequently documented is the use of hybrid restorations which are both cemented and screwed. Nonetheless, besides the evident biomechanical advantages of cement-retained prostheses, most clinicians still opt for screw-retained due to the retrievability inherent to such assemblies (MICHALAKIS; HIRAYAMA; GAREFIS, 2003). It is worth to mention that the concern in supported prostheses cementation lies on ranking various cements to establish a guide for clinicians since retrievability and longevity in cement-retained prosthesis with provisional cements has been previously reported (KIM, et al., 2006; WORNI, et al., 2015). Also, not only the adhesive bond strength is important to cementation longevity but also mechanical factors, such as frictional resistance (COVEY, et al., 2000; SCHIESSL, et al., 2013). Then, final prostheses retention depends on cement type, abutment height and texture, fit of the superstructure and prosthesis material composition (KENT; KOKA; FROESCHLE, 1997; COVEY, et al., 2000; SCHIESSL, et al., 2013).

Ti-base abutments are a somewhat novel concept that can be indicated not only for conventionally cemented rehabilitations but also as a link between implant and a monolithic customized crown or a high-strength customized ceramic abutment joint to a cement-retained crown (screwed three-piece restorations). The main advantages of such concept, as previously explained, comprise the absence of ceramic material inside the implant connection, reproduction of a tailored emergence profile, and last but not the least, the opportunity of performing the bonding procedure before crown placement. Such sequence of procedures support a final bond area polishing that decrease soft tissue reaction regarding remnants of cement (PAULETTO; LAHIFFE; WALTON, 1999; RODRIGUEZ et al., 2017). Nonetheless, 
literature findings are scarce in addressing the influence of Ti-base height and cement type regarding to abutment-to-crown retention (GEHRKE, et al., 2017).

The abutment geometry, mainly taper degree and height, has been previously shown to affect the retentiveness of implant supported rehabilitations (KENT, KOKA FROESCHLE, 1997; BERNAL; OKAMURA; MUNOZ, 2003). In the present study, taper degree was standardized by the manufacturer, and the force to dislodgment for $4.0 \mathrm{~mm}$ (tall) and $2.5 \mathrm{~mm}$ (short) Ti-base abutments were compared. Both abutment cone heights demonstrated similar retentive force (data collapsed over cement). Even when data were evaluated as a function of both factors, similar force to dislodgment between tall to short abutments for all within cement comparisons was evidenced, except for U200. Consequently, the first postulated null hypothesis that Ti-base abutment height would not influence pull-out retention values was accepted. This result is in contrast to previous literature findings that have shown that the higher the abutment's axial walls or the height to width ratio the better the effect on the uniaxial testing values due to higher contact area (KENT, KOKA FROESCHLE, 1997; BERNAL; OKAMURA; MUNOZ, 2003). In one investigation, an approximately 1.5-mm-height increase in the axial wall of standard abutments $(3.6 \mathrm{~mm})$ evidenced twice retention strength values(KENT, KOKA FROESCHLE, 1997).

Previous studies have demonstrated that provisional cements can satisfactorily work for conventional cement-retained implant supported crowns (KIM, et al., 2006; WORNI, et al., 2015). Consequently, the second postulated null hypothesis of the current study consisted on the assumption that cement type would not influence pull-out retention values, even for Ti-base abutments that possess a screw access. Nonetheless, the results demonstrated that resin-based cements presented significantly higher force to dislodgment relative to provisional and glassionomer groups, without significant difference between both resin cements and also between provisional and glass-ionomer cement (data collapsed over Ti-Base height). The same behavior was evidenced when data were evaluated as a function of both factors with resin-based cements demonstrating similar force to dislodgment between tall to short abutments and both significantly more retentive than tall and short provisional and Meron cements. This rank order corroborates with previous studies that evaluated pullout retention values for metal abutments with different cements (SCHIESSL, et al., 2013; GARG; PUJARI; KHARE, 2014). 
The absence of significant difference between both resin-based cement lies behind their similar composition (methyl methacrylate monomers) (PASSOS, et al., 2010). The lack of an adhesive layer between zirconia superstructure and resinbased cements has been previously shown to hamper bond strength (AB-GHANI, et al., 2015), however, the retention is proposed to be improved with use of chemical surface treatments such as the addition of phosphate groups in the cement system (HILL; LOTT, 2011; PAPIA, et al., 2014). Both cements tested in the current study presented phosphate groups; self-adhesive U200 cement presents such monomers in its composition and Ultimate, even as a conventional cement, is recommended to be used with an adhesive system that also present MDP in its composition. On the other hand, the notably lower pullout retention values for glass-ionomer and provisional cements are based on the absence or weak bond to zirconia due to lack of any bonding agent, as previously reported (ROHR, et al., 2017).

Although time-consuming, the pullout test is an efficient alternative to determine the retentive force of abutment joint to zirconia restorations. Such a test is influenced by several factors such as the degree of fit, height of the planned restoration, taper angle and luting agent (HEINTZE, 2010). Consequently, the general coincidence with literature findings allows us to conclude that the rank ordering of the cements in the current study is valid. Actually, there is no determination based on what constitutes a minimum pullout value that provides long retentiveness to an implant supported rehabilitation so that the patient would not have to return for prostheses recementation at an unexpected time. Then, the current and previous studies provide a scenario of the bonding behavior of various cements and abutment designs that may be used as a guide until clinical studies are conducted (SHEETS; WILCOX; WILWERDING, 2008). 

4 CONCLUSION 



\section{CONCLUSION}

While Ti-base abutment height have not influenced zirconia superstructure retentiveness, resin-based cements significantly evidenced higher retention than glass ionomer and temporary cements. 



\section{REFERENCES}





\section{REFERENCES}

Ab-Ghani Z, Jaafar W, Foo SF, Ariffin Z, Mohamad D. Shear bond strength of computer-aided design and computer-aided manufacturing feldspathic and nano resin ceramics blocks cemented with three different generations of resin cement. J Conserv Dent 2015;18:355-359.

Bernal G, Okamura M, Munoz CA. The effects of abutment taper, length and cement type on resistance to dislodgement of cement-retained, implant-supported restorations. J Prosthodont 2003;12:111-115.

Breeding LC, Dixon DL, Bogacki MT, Tietge JD. Use of luting agents with an implant system: Part I. J Prosthet Dent 1992;68:737-741.

Covey DA, Kent DK, St Germain HA, Jr., Koka S. Effects of abutment size and luting cement type on the uniaxial retention force of implant-supported crowns. J Prosthet Dent 2000;83:344-348.

Garg P, Pujari ML, D RP, Khare S. Retentiveness of Various Luting Agents Used with Implant Supported- Prosthesis: An Invitro Study. J Oral Implantol 2014.

Gehrke P, Alius J, Fischer C, Erdelt KJ, Beuer F. Retentive strength of two-piece CAD/CAM zirconia implant abutments. Clin Implant Dent Relat Res 2014;16:920925.

Goodacre CJ, Kan JY, Rungcharassaeng K. Clinical complications of osseointegrated implants. J Prosthet Dent 1999;81:537-552.

Gracis S, Michalakis K, Vigolo P, Vult von Steyern P, Zwahlen M, Sailer I. Internal vs. external connections for abutments/reconstructions: a systematic review. Clin Oral Implants Res 2012;23 Suppl 6:202-216.

Gracis S, Thompson VP, Ferencz JL, Silva NR, Bonfante EA. A new classification system for all-ceramic and ceramic-like restorative materials. Int J Prosthodont 2015;28:227-235. 
Hebel KS, Gajjar RC. Cement-retained versus screw-retained implant restorations: achieving optimal occlusion and esthetics in implant dentistry. J Prosthet Dent 1997;77:28-35.

Heintze SD. Crown pull-off test (crown retention test) to evaluate the bonding effectiveness of luting agents. Dent Mater 2010;26:193-206.

Hill EE, Lott J. A clinically focused discussion of luting materials. Aust Dent J 2011;56 Suppl 1:67-76.

Hjalmarsson L, Gheisarifar M, Jemt T. A systematic review of survival of single implants as presented in longitudinal studies with a follow-up of at least 10 years. Eur J Oral Implantol 2016;9 Suppl 1:S155-162.

Inokoshi M, De Munck J, Minakuchi S, Van Meerbeek B. Meta-analysis of bonding effectiveness to zirconia ceramics. J Dent Res 2014;93:329-334.

Karoussis IK, Bragger U, Salvi GE, Burgin W, Lang NP. Effect of implant design on survival and success rates of titanium oral implants: a 10-year prospective cohort study of the ITI Dental Implant System. Clin Oral Implants Res 2004;15:8-17.

Kent DK, Koka S, Froeschle ML. Retention of cemented implant-supported restorations. J Prosthodont 1997;6:193-196.

Kim Y, Yamashita J, Shotwell JL, Chong KH, Wang HL. The comparison of provisional luting agents and abutment surface roughness on the retention of provisional implant-supported crowns. J Prosthet Dent 2006;95:450-455.

Lee A, Okayasu K, Wang HL. Screw- versus cement-retained implant restorations: current concepts. Implant Dent 2010;19:8-15.

Michalakis KX, Hirayama H, Garefis PD. Cement-retained versus screw-retained implant restorations: a critical review. Int J Oral Maxillofac Implants 2003;18:719-728. 
Ozcan M, Bernasconi M. Adhesion to zirconia used for dental restorations: a systematic review and meta-analysis. J Adhes Dent 2015;17:7-26.

Papaspyridakos P, Chen CJ, Singh M, Weber HP, Gallucci GO. Success criteria in implant dentistry: a systematic review. J Dent Res 2012;91:242-248.

Papia E, Larsson C, du Toit M, Vult von Steyern P. Bonding between oxide ceramics and adhesive cement systems: a systematic review. J Biomed Mater Res B Appl Biomater 2014;102:395-413.

Passos SP, May LG, Barca DC, Ozcan M, Bottino MA, Valandro LF. Adhesive quality of self-adhesive and conventional adhesive resin cement to Y-TZP ceramic before and after aging conditions. Oper Dent 2010;35:689-696.

Pauletto N, Lahiffe BJ, Walton JN. Complications associated with excess cement around crowns on osseointegrated implants: a clinical report. Int J Oral Maxillofac Implants 1999;14:865-868.

Pjetursson BE, Sailer I, Makarov NA, Zwahlen M, Thoma DS. Corrigendum to "Allceramic or metal-ceramic tooth-supported fixed dental prostheses (FDPs)? A systematic review of the survival and complication rates. Part II: Multiple-unit FDPs" [Dental Materials 31 (6) (2015) 624-639]. Dental materials : official publication of the Academy of Dental Materials 2017;33:e48-e51.

Pjetursson BE, Tan K, Lang NP, Bragger U, Egger M, Zwahlen M. A systematic review of the survival and complication rates of fixed partial dentures (FPDs) after an observation period of at least 5 years. Clin Oral Implants Res 2004;15:667-676.

Rodriguez LC, Saba JN, Chung KH, Wadhwani C, Rodrigues DC. In vitro effects of dental cements on hard and soft tissues associated with dental implants. J Prosthet Dent 2017;118:31-35.

Rohr N, Brunner S, Martin S, Fischer J. Influence of cement type and ceramic primer on retention of polymer-infiltrated ceramic crowns to a one-piece zirconia implant. $\mathrm{J}$ Prosthet Dent 2017. 
Sailer I, Makarov NA, Thoma DS, Zwahlen M, Pjetursson BE. Corrigendum to "Allceramic or metal-ceramic tooth- supported fixed dental prostheses (FDPs)? A systematic review of the survival and complication rates. Part I: Single crowns (SCs)" [Dental Materials 31 (6) (2015) 603-623]. Dental materials : official publication of the Academy of Dental Materials 2016;32:e389-e390.

Schiessl C, Schaefer L, Winter C, Fuerst J, Rosentritt M, Zeman F, et al. Factors determining the retentiveness of luting agents used with metal- and ceramic-based implant components. Clin Oral Investig 2013;17:1179-1190.

Schwarz S, Schroder C, Corcodel N, Hassel AJ, Rammelsberg P. Retrospective comparison of semipermanent and permanent cementation of implant-supported single crowns and FDPs with regard to the incidence of survival and complications. Clin Implant Dent Relat Res 2012;14 Suppl 1:e151-158.

Sheets JL, Wilcox C, Wilwerding T. Cement selection for cement-retained crown technique with dental implants. J Prosthodont 2008;17:92-96

Wittneben JG, Joda T, Weber HP, Bragger U. Screw retained vs. cement retained implant-supported fixed dental prosthesis. Periodontol 2000 2017;73:141-151.

Worni A, Gholami H, Marchand L, Katsoulis J, Mericske-Stern R, Enkling N. Retrievability of implant-supported crowns when using three different cements: a controlled clinical trial. Int J Prosthodont 2015;28:22-29. 
ANNEX 

The Imeornational soumel of

Prosthodontics will consider for publication original articles on relevant prosthodontic clinical research and patients' oral rehabilitative needs. The submitted articles must not have been published or submitted for publication elsewhere. Articles may be submitted as Long ( $\mathrm{LC}$ ) or Short Communications (SC) with both formats undergoing identical (SC). processes. Papers dealing with the clinical management of prosthodontic patients or clinically relevant biomaterials investigation are more likely to be accepted as $L$ igations (a) laboratory investigations, pilot or preliminary studies, and case history reports should b preferably submited as SCs. The Editor-in Chief reserves the right to request that an author change a submission from an LC to an $\mathrm{SC}$, or vice versa.

\section{Submil manuscripts to UPs online aubmission service: www.manuscriptmanager.com/1jp}

Manuscripts should be uploaded as PC Word (doc) files with tables and figures preferably embedded within the document. No paper version is rexquired.

Review/editing of manuscripts. Manuscripts will be reviewed by the editor-in-chief one associate editor, and one or two reviewers or consultants with expertise within the scope of the article Papers the conclusions from statistical draw conclusions from statistical evidence may be revewed by a statistical consultant The p lisher reserves the right to edit accepted manuscripts to fit the space available and to
ensure conciseness, clarity. and stylistic consistency, subject to the author's final approva

Adherence to guidelines. Manuscripts that are not prepared in accordance with these guidelines will be retumed to the author before review.

\section{Manuscript Preparation}

The Journal will follow as much as possible the recommendations of the International Committee of Medical Journal Editors (Vancouver Group) in regard to preparation of manuscripts and authorship (Uniform Remanuscripts and authorship (Uniform ReQuirements for Manuscripts Journals, updated October 2008 www.icmje.org).

Short Commeunicadtons Short Communications must not exceed 700 words. 4 illustrations with concise legends, and 5 references.
Maruscripts should be typed double-spaced with a 1-inch margin all around. Number all pages. Do not include author names as headers or footers on pages

- Title page. This shoukl include the title of the article (descriptive but as concise a possible) and the name, degrees, title. professional affiliation, and full address of all authors. Phone, fax and e-mail address must also be provided for the

must also be provided for the corresponding author, who will be assumed to be the first-listed author unless otherwise
noted. If the paper was presented before an organized group, the name of the organization, location, and date should be included.

- Abstract/key words. For Long

Communications, include a maximum 250 word structured abstract (with headings

Aims. Methods. Results. Conclusion) and 5 key words. Short Communications should include a 100 -word abstract that can be published on PubMed.

- Introduction. Sum riarize the rationate and Introductlon. Sum rarize the rationale and purpose of the study. giving only pertin
references. Clearly state the iworking

references.

Materials and Methods. Present material and methods in sufficient detail to allow confirmation of the observations. Published methods should be referenced and discussed only briefly, unless modifications have been made. Indicate

the statistical methods used, if applicable.

- Results. Present results in a logical sequence in the text, tables, and illustrations. Do not repeat in the text all the data in the tables or illustrations: emphasize only important observations

- Discussion. Einphasize new and important aspects of the study and the conclusions that follow from them. Do not repeat in detail data or other materal ginen in the detail data or other material given in the Introduction or Results section. Relate
observations to other relevant studies. poin out the implications of the findings and their limitations.

- Acknowledgments. Acknowledge person who have made substantive contributions to who have made substantive contributions the study. Specify grant or other financial support, citing the name of the

organization and grant number. Figure Legends. Figure legends should be double-spaced.

- Abbreviations. The full term for which an abbreviation stands should precede its firs use in the text unless it is a standard unit of measurement.

- Trade names. Genenc terms are to be used whenever possible, but trade names and manufacturer should be included parenthetically at first mention.
Relerences

All references must be cited in the text, numbered in order of appearance.

The reference list shouid appear at the end of the anticle in numeric sequence

- Do not include unpublished data or

personal communications in the reference list Cite such references parenthetically in the text and include a date.

- Avoid using abstracts as references.

- Provide complete information for each reference, including names of all authors (up to six). If the reference is to part of a book, also include the title of the chapte and names of the book's editor(s).

Joumal reference style:

1. Zitzmann NU. Rohner U, Weiger R, Krastl G When to choose which retention element to use for removable dental prostheses. Int $\mathrm{f}$ Prosthodont 2009:22:161-167.

Book reference style:

1. Jacob RF. Clinical management of the edentulous maxillectomy patient in: Taylor TD (ed). Clinical Maxillofacial Prosthetics.

Chicago Quintessence, 2000-85-102

\section{Illustrations and Tables}

- All illustrations and tables should be numbered and cited in the text in order of appearance.

- Illustrations and tables should be embedded in the Word document - All illustrations and tables should be grouped at the end of the text.

- High-resolution digital images or origina slides must be semt to the Publisher's office upon acceptance of the article.

- Note that article acceptance is pending

receipt of acceptable originel art

Mandatory Submiesion Form

The Mandatory Submission Form must be signed by all authors and faxed to the Publisher's office $(+6307363634)$.

\section{Permissions and Waivers}

- Permission of author and publisher mus be obtained for the direct use of matena (text, photos, drawings) under copyright that does not belong to the author

- Waivers inust be obtained for photographs showing persons. When such waivers are not supplied. faces will be cropped to prevent identification.

- Permissions and waivers should be faxed along with the Mandatory Submission Form to the Publisher's office ( +6307363634$)$. 